\title{
SPEKULAATION MATERIAALINEN PALUU JA VÄLTTÄMÄTÖN KONTINGENSSI
}

\begin{abstract}
LEVI BRYANT, NICK SRNICEK \& GRAHAM HARMAN (toim.):The Speculative Turn: Continental Materialism and Realism. RE.PRESS 2011
\end{abstract}

MARKUS GABRIEL \& SLAVOJ ŽIŽEK: Mythology, Madness and Laughter. Subjectivity in German Idealism. Continuum 2009.

QUENTIN MEILLASSOUX: Après la finitude. Seuil 2006.

\section{JOHDANNOKSI : HENGEN HAJOAMISPROSESSI}

Marxin Saksalaisen ideologian alun sanoin Saksa koki Hegelin kuoleman jälkeen "vertaansa vailla olevan mullistuksen". Hegelin järjestelmän ja absoluuttisen hengen hajoamisprosessi alkoi heti sen viimeisen elämänkipinän sammuttua ja kehittyi pian maailmanlaajuiseksi käymistilaksi. Puhtaan ajattelun alueella käynnistyi prosessi, jossa kuollut organismi, sen caput mortum hajosi osiin, tai kuten Marx kirjoittaa: "Se oli vallankumous, johon verrattuna Ranskan vallankumous oli lastenleikkiä, maailmankamppailu, jonka rinnalla diadokien taistelu näyttää näpertelyltä. Periaatteet tunkivat toisiaan syrjään ja 'hengenjättiläiset' kukistivat toisiaan ennen kuulumattomalla kiireellä, ja kolmessa vuodessa, 1842-1845, Saksassa lakaistiin enemmän kuin sitä ennen kolmeen vuosisataan." Tätä mullistusta seuranneessa filosofian markkinahumussa ei ollut enää mitään tietoa absoluutista. Marx selvittää, kuinka "filosofian tehtailijat" tarttuivat siihen, mitä vain kullekin käteen sattui, ja alkoivat "mahdollisimman uutterasti kaupitella" tätä kohdalle sattunutta absoluutin osaa. Tämä kaupittelu sujui sivistyneesti kunnes markkinat kyllästyivät ja, kuten Marx kirjoittaa, "liikeyritys pilattiin tavalliseen saksalaiseen tapaan tusina- ja korviketuotteilla, laatua huonontamalla, raaka-aineita sotkemalla, etikettejä väärentämällä, nimelliskaupoilla, vekselipelillä ja luottojärjestelmällä kokonaan vailla reaalikatetta."

Sittemmin absoluutin aave on aina aika ajoin palannut kummittelemaan ja pannut käyntiin niin ajattelun projekteja kuin toimintaakin. Tämä voi kyllä tietyn hegeliläisyyden näkökulmasta todella tarkoittaa loppua ja vain lopun jälkeistä nostalgista muistelua, mutta sen sijaan Hegel itse saattaa olla hankalampi tapaus ja itse asiassa tällaisena käymistilana ja kummitteluna olla elossa enemmän kuin koskaan. Kyseinen vaikutelma syntyy ainakin siinä keskustelussa, joka on viime vuosina virinnyt "spekulaation paluun" ja "spekulatiivisen käänteen" nimissä ja jota tuoreessa The Speculative Turn -teoksessa hahmotetaan ranskalaisen nykyajattelun uutena - jos 60-70-luvun sukupolvi, Foucault, Deleuze ja Derrida, oli edellinen - maailmalle levinneenä aaltona.

Jos se, mikä Hegelin jälkeen kuoli ja Marxin sanoin "lahosi", oli aistimelliseksi ja siten läsnäolevaksi käsitetty absoluutti filosofian orgaanisena systeeminä, tämä kuolema seurasi siitä ilmeisestä ristiriidasta, josta se kärsi suhteessa objektiiviseen ja tervejärkiseen todellisuuteen. Filosofinen absoluutti, siis absoluuttinen filosofian asiana, ei voi muuta kuin hajota osiin, jos filosofia itse ei kerran ole tuo todellinen, vaan puhtaana ajatteluna eroaa aistimellisesta ja objektiivisesta, siis sikäli kuin filosofia käsitetään ajatteluksi erotettuna todellisuudesta.

Marxin viittaus Ranskan vallankumoukseen onkin osuva: yhtä lailla kuin Ranskan vallankumous ja sitä seurannut terrorin tila on valistuksen projektin käsitteellisesti välttämätön seuraus, siis yhtä lailla kuin yksinkertaisesti tietokyvyn rajattomuudeksi käsitetty valistus päätyy tilaan, jossa kuka tahansa saattaa huutaa "Minä olen valtio!", niin myös läsnäolevaksi käsitetyn absoluutin elämänkipinän täytyy todellakin välttämättä hiipua, sen ruumiin hajota ja kirjaimellisesti haihtua taivaan tuuliin.

Siten voi tosiaan olla että saksalaiseen tapaan pilattu liikeyritys lopetti absoluutin ajattelun perinteen. Ongelma tässä toiveessa päästä eroon spekulatiivisesta absoluutista on kuitenkin se, että kyse saattaa olla nimenomaan Hegelin omasta väiteestä. Tätähän $\mathrm{He}-$ gel nimittäin väsymättömästi toistaa: todella vaikutuksellinen - ja tässä mielessä todellinen - absoluutti on mahdollinen vasta siitä pisteestä käsin, jossa sen yksittäisen esityksen mahdottomuus on tullut läpikotaisin selväksi. Näin Marxin kuvaama absoluutin hajoamisprosessi, hengen läsnäolon mahdottomuuden ilmiö, on paljon enemmän Hegelin mukainen kuin hegeliläisyys koskaan.

\section{SPEKULAATION PERINNE:}

KANT JA HEGEL ABSOLUUTIN LÄSNÄOLOSTA

Jos länsimaisen ajattelun modernia perinnettä jäsentää sen kautta, mikä kulloinkin on ajattelua vaivaava sudenkuoppa tai ikään kuin perustava väärinkäsitys, josta kukin ajattelija pyrkii pääsemään eroon ja jonka purkamisesta kukin projekti muodostuu, saksalaisen idealismin tapauksessa se on tietty absoluutin läsnäolon vaara. Kantista lähtien filosofian tehtäväksi käsitetään abso- 
luuttisen ajatteleminen, mutta niin, että tuon tehtävän toteuttaminen voi alkaa vasta sen jälkeen, kun ensin on purettu se jokapäiväistä kokemusta määrittävä harha, että meillä todella on käsissämme ja tietokykymme ulottuvilla jotakin epäilemätöntä.

Tämä on tottakai ylipäätään uuden ajan projektin ja kartesioilaisuuden perustava asetelma. Yleinen tulkintahan on se, että Descartes'n jälkeen filosofia käsittää itsensä kysymykseksi subjektista, yhtäältä sen kyvystä tietää ja toisaalta olla varma tiedostaan. Jos filosofia tässä muodossa on Descartes'lle ristiriita tiedon subjektin äärellisyyden ja välttämättömältä vaikuttavan äärettömyyden välillä, Kant kääntää tämän jäsennyksen kysymykseksi sellaisesta transsendentaalisuudesta, joka kuuluu subjektille itselleen ja nimenomaan sen olemukseen eikä millekkään ylimmälle olevalle tai ylipäätään subjektin ulkopuoliselle taholle. Äärellistä kokemusta kyllä ehdollistavat tietyt ulottumattomissa olevat tekijät, niin puhtaat käsitteet kuin olio sinänsäkin, mutta nämä eivät kuitenkaan ole subjektin ulkopuolella. Ne ovat vain ajattelulle. Ne eivät ole annettuja aistimellisuudelle, vaan ajattelulle, jolloin ne eivät koskaan voi olla käsillä - ja siltikin ne aina jo ovat, mutta ilman läsnäoloa. Ne ovat ikuisesti melkein täällä. Siten intuitio, asioiden saaminen käsille, on Kantille aistimellinen, ei koskaan yli-aistimellinen.

Tässä yhteydessä koko Kantin projektia liikuttaa tarve torjua tuona aikana paljon kiinnostanut intellektuaalisen intuition mahdollisuus. Kantille tämä järjen läsnäolo on näin torjutun ja kielletyn negatiivista läsnäoloa. Se on ideoiden läsnäoloa ajattelussa, mikä aistimellisuuden kannalta tarkoittaa velvoittumista niiden äärettömään lähestymiseen ja torjumiseen. Kyseinen kireä ristiriita on Kantin mukaan läsnä subjektin ei-subjektiivisena tunteena, suhteessa moraalilakiin tunnettuna kunnioituksena, kauniin ja ylevän tunteen jaettavuutena käsitteellisen yleisyyden tuollapuolen. Hegelille, joka ei suostu lukemaan subjektin tunnetta muuten kuin välittömänä, tämä kaikki on pelkkää kaunosieluisuutta, kaikin tavoin arveluttavaa subjektiivisuutta.

Hegelin väite suhteessa Kantiin onkin se, että jos aistimellinen ei ole todellista, ajattelu aistimellisen ylittävänä määrittyy pelkästään negatiivisesti. Kantille järki on läsnä aistimellisuuden piirissä vain kiellon kautta. Siksi Hegelille on selvää, että Kantin ajattelu on pelkästään fenomenologiaa ja jää siis kiinni kokemuksen ja äärellisen tietoisuuden näkökulmaan. Kantille, ja kaikelle sellaiselle tervejärkiselle ajattelulle, jonka lähtökohtana on kokemus, jää myyttiseksi se, minkä pitäisi olla loogista: että kokemuksen tuottavat prosessit, siis ajattelu, on aina jo tapahtunut ennen yksittäisen subjektin puhkeamista syviin sisäisiin mietiskelyihinsä. Absoluutti on aina jo ollut täällä.

Näin sekä Kant että Hegel tekevät saman perustavan havainnon: absoluuttinen ei ole läsnäoleva. Kuitenkin siinä, missä kantilaisuutta on päätös alkaa ajatella aistimisen ja tietämisen sijaan, hegeliläisyys on sitä, että tiedetään ja tehdään tiedettä absoluutista, joka ei ole tiedon piirissä. Hegelin näkökulmasta Kantin varsinainen filosofia on kuollutta - ja elävää vasta siellä, missä se ei enää ole filosofiaa vaan taidetta. Hegel kritisoi Kantia siten siitä, että filosofia jää hä- nellä psykologisen fakulteetin alaisuuteen eikä sitä käsitetä tieteeksi. Kritiikki kytkeytyy sittemmin Kantin jälkeisessä saksalaisessa idealismissa paljon esillä olleeseen, esimerkiksi Fichten myöhäisajattelussaan korostamaan ajatukseen, jonka mukaan totuuden diskurssissa ei ole kyse minän vaan jonkun muun tahon ykseydestä, yksinkertaisimmillaan tieteen monikollisesta ei-läsnäolevasta subjektista, meistä. Kantin jälkeen ajattelun läsnäolo itselleen on kyllä reaalista ja todellista, mutta jossakin sellaisessa mielessä, jossa se on kokemuksellista objektiivisuutta reaalisempaa.

Kantin jälkeinen saksalainen idealismi tekee siis suhteessa edeltävään perinteeseen sen eron, että ajattelun performatiivisuus, sen oma tapahtuminen, ei siinä jää enää filosofisen esityksen ulkopuolelle. Hegelille tämä ajattelun tapahtumisen taso tarkoittaa sitä, että käsitteen todellistuminen on mahdollista vain jos huomioidaan, että henki todella nousee markkinahumun keskeltä ja raunioista. Ajattelulla on siten Hegelin mukaan objektiivinenkin taso, jolla se on meidän konkreettinen todellisuutemme poliittisena ja taloudellisena. Ajattelun kannalta tässä objektiivisuudessa on kuitenkin oleellista vain siinä tapahtuva muutos, sellainen ilmaantuminen ja häviäminen, joka ei palaudu luonnolliseen jatkumiseen vaan jossa asiat tulevat, kääntyvät ympäri ja häviävät jäljettömiin. Tässä mielessä kuninkaan on todella menetettävä päänsä, jotta vapaus pääsisi olemaan sitä mitä se on. Samalla oleellista on se, että siinä kohtaa, missä hengen objektiivinen taso todella johtaa historialliseen tietoisuuteen, ei ole saatavilla mitään sovituksen tarjoavaa objektiivista tapahtumaa. Subjekti 
löytää historiasta pelkästään oman ei-objektiivisuutensa. Sen tapaama objektiivinen löytö on pelkästään sitä, että absoluuttista on objektiiviseksi käsitetyn ääretön vapaus olla aina jotakin muuta kuin mitä se on. Kun absoluuttinen henki ajattelun läsnäolona ja totuuden diskurssina syntyy käsitteellisesti (siis filosofian tieteen näkökulmasta) maailmanhistorian jälkeen, niin voisi luulla, että näin henki ikään kuin todella ja historiallisesti "laskeutuu maan päälle". Kokemuksen kannalta hengen maan päälle laskeutuminen tarkoittaa Hegelin mukaan kuitenkin vain sitä valistuksen jälkitilaa, jonka totuus paljastuu vallankumousta seuraavassa terrorin tilassa.

Siten on helppo käsittää väärin, että Hegelillä absoluutti olisi historiallisesti objektiivinen, siis että tosiasiahistoria olisi ontologisesti perustava. Kuten yleisesti toistellaan, henki on Hegelille historiallinen. Tässä kohtaa Hegel-luentaa kannattaa kuitenkin pysähtyä. Historiallisen ja käsitteellisen liikkeen ero nimittäin vilahtaa totutusti ohi silmiemme. Väärinkäsitys, jonka piirin voi lukea monet Hegel-tulkinnat aina Kojèveen ja Heideggeriin saakka, syntyy siis siitä Hegelin kannalta katsoen kaunosieluisesta päätelmästä, että jos läsnäoloon ei kerran päästä kiinni tässä ja nyt, niin sitten sen voi tavoittaa historiallisesti: muutoksen ja tapahtumisen etusijan myöntämisen jälkeen voi aina koettaa hetken nauttia asioiden historiallisuudella viisastelusta.

Se epä-hegeliläinen Hegel, joka näyttää palaavan itsepintaisesti oman kuolemansa jälkeen, on kuitenkin hankalampi. Käsitteen kehitys on nimittäin kokonaan toista kuin ajallinen ja historiallinen kehitys. Tätä erottelua voi epäillä ja se voi monin paikoin olla hankalasti ulosluettava, tai kuten Jean Hyppolite toteaa, "tässä kohtaa Hegelin ajattelu jättää meille lähes ylitsepääsemättömiä vaikeuksia”, mutta vasta tätä vaikeutta vasten spekulatiivinen ajattelu voi olla yhtään mitään muuta kuin mennyttä. Tämän vaikeuden kohdalta, kuten Hyppolite samassa yhteydessä kirjoittaa, "on löydettävissä Hegelin ajattelun vääntö".

\section{KANTILAINEN KATASTROFI JA DESCARTES'N PERINTÖ}

Kaksi asiaa ovat Hegelin ajattelusta esitetyissä tulkinnoissa tuskin koskaan käyneet yksiin: absoluutti ja tapahtuma, siis yhtäällä Hegelin korostama ajattelun kohteen ehdoton välttämättömyys ja toisaalla asioiden kontingenssi, välinpitämättömyys ajattelun suhteen.

Hämmästyttävän monet ja moninaiset tulkinnat ottavat itsestäänselvyytenä, että Hegelillä tapahtumisen ja olioiden itsenäisyyden ulottuvuutta ei yksinkertaisesti ole. Vielä Heideggerillekin Hegelin käsitteellistämä tapahtuminen "lankeaa tavanomaisesti tulkittuun aikaan". Karkeasti sanottuna Hegelin absoluutti, asioiden käsitteellinen välttämättömyys, on otettu yksinkertaisesti historiallisena. Äärimmillään Hegel vaikuttaa Kojèven lukemana väittävän, että maailmanhistoria loppuu sen liikkeen päätepisteessä, jota Hegelin kokemuksen tiede, Hengen fenomenologia kuvaa. Ei kuitenkaan tarvitse lukea montaakaan riviä Hengen fenomenologiaa, puhumattakaan Logiikan tieteestä, että selviää kuinka absoluuttinen tieto ei ole mitään muuta kuin kokemuksen tieteen loppu, tieto yksittäisen tietoisuuden saavutettavissa olevan totuuden mahdottomuudesta.
Siksi Marxin kuvaamaa absoluutin hajoamista seurannut kummittelu vaikuttaakin enemmän Hegeliltä kuin hegeliläisyys koskaan. Siinä nimittäin konkreettiseksi tulkitun absoluutin elämän ajattelu muuntuu jossakin muussa mielessä tulkitun elämän ajattelemiseksi. Hegelille itselleen elämä on nimenomaan looginen kategoria, mutta nykyajattelun kannalta tässä on tarjolla tietty ratkaisun paikka. Miten tämä jako ajallishistoriallisen ja loogisen välillä tulkitaan?

Jaon voisi asettaa esimerkiksi niin, että läsnäolevan elämän hajoamisen jälkeen on tarjolla kaksi vaihtoehtoa: joko päädytään ajattelemaan sellaista messiaanista ja ikään kuin kvasi-transsendentaalista elämää, jonka läsnäolo on Derridan sanoin "tässä ja nyt ilman läsnäoloa", tai sitten ajatellaan tätä ajattelun läsnäolon menetystä objektissa.

Olisi ehkä liian helppoa sanoa, että ensimmäiseen suuntaan lähtevät modernin ajattelun kaikki kantilaiset Heideggerista ja yleisemminkin fenomenologiasta aina Derridaan asti. Vaikka tämä on tottakai liian yksinkertaista, tietty ero on kuitenkin merkille pantavissa. Vaikka esimerkiksi Derridan ajattelusta on esitetty toisenlaisiakin tulkintoja, voi hyvin väittää, kuten esimerkiksi Slavoj Žižek on tehnyt, että tällainen lähtökohdaltaan transsendenssia korostava ajattelu, olkoonkin sitten kyse kvasi-transsendenssista tai immanentista transsendenssista, on yhtä kaikki transsendentaalista ajattelua, jolle on oltava vaihtoehto. Tämän vaihtoehdon voisikin sanoa nostaneen viimeaikoina päätään spekulatiivisuuden paluun eri muodoissa. Jos merkityksellisen maailman täysi läsnäolo, idea, käsitetään poissaolevaksi, 
joksikin mikä ikuisesti tulee ja joka on täällä olemalla tuleva, ajatellaan ja vaalitaan siis transsendenssia. Edellä ehdotetun jakolinjan toisella puolella on vaihtoehto, jossa tätä tulemista tarkastellaan objektissa. Jakolinja voidaan suhteuttaa edellä avattuun Hegelin ja Kantin eroon: sikäli kun uusi transsendentaalinen ajattelu syntyy välttämällä kantilainen sudenkuoppa, siis onnistumalla pitämään transsendenssi ikuisesti auki, niin uusi immanentti ajattelu puolestaan syntyy välttämällä Hegelin sudenkuoppa.

Spekulatiivista realismia ja materialismia koskevan keskustelun avanneen Quentin Meillassoux'n teoksen Après la finitude (suom. Äärellisyyden jälkeen) mukaan onkin itse asiassa niin, että ainoa koko länsimaista ajattelua vaivaava sudenkuoppa on Kant. Kantin ajattelu ja erityisesti siitä perinteeseen pesiytyvä äärellisyys on katastrofi, jonka tuolle puolen pitäisi päästä. Äärellisyyden jälkeisyys viittaa kokonaan uuteen ajatteluun. Se avaa, kuten Alain Badiou mainittuun teokseen kirjoittamassaan esipuheessa sanoo, "kokonaan uuden polun filosofian historiassa”. Sellaisenaan Meillassoux ei kuitenkaan väitä alkavansa tyhjästä vaan esittää, että ajattelun olisi, viime vuosisadan ajattelun näkökulmasta hyvin epätavallisella tavalla, tehtävä tietty paluu kartesiolaisuuteen, etsittävä Descartes'n perintö uudelleen kantilaisen virheen takaa. Mitä nämä Descartes'n perintö ja Kantin katastrofi sitten ovat?

Siinä missä Descartes sijoittaa subjektin varmuuden tietokyvyn ulkopuoliseen äärettömään olioon ja sen selvään ja kirkkaaseen tietämiseen, Kantille tämä varmuus on vain tietty subjektin sisäisen toiminnan funktio. Kun Descartes'ille ääretön olento on olemassa siksi, että sen olemassaolon puuttuminen olisi ristiriidassa sen täydellisyyden kanssa, Kantille jumala lakkaa olemasta siksi, että ristiriita kuuluu järjen ja ymmärryksen antinomisuuteen ja on tällaisena ajateltavissa. Descartes siis johtaa matemaattiseksi tulkitsemansa absoluuttisen kuvauskyvyntäydellisen olennon olemassaolon pohjalta. Matematiikka kuvauksena absoluuttisesta turvaa asemansa sen kautta, että on olemassa täydellinen ääretön olento suhteessa äärelliseen tietämiseen.

Meillassoux'n tulkinnassa kantilainen katastrofi syntyy siten siitä, että tästä lähtien matematiikka, joka Descartes'ille on nimenomaan filosofian ehdoton kuvaus, kuvaa enää vain subjektin aistimellisuuden muotoa. Meillassoux käsittää tämän niin, että näin perinne Kantin kohdalla hukkaa kokonaan oman tehtävänsä, siis tehtävän ajatella absoluuttia.

Tästä huolimatta Meillassoux ei kuitenkaan vaadi paluuta Kantia edeltävään vanhaan metafysiikkaan. Descartes'n jälkeen tarvitaan kyllä tietty kriittisen filosofian projekti. Mutta vaikka äärettömän olennon olemassaolosta on luovuttava, jotta filosofia voisi olla mitään muuta kuin dogmaattista metafysiikkaa, tapa, jolla Kant tämän tekee, on myöhemmän perinteen kannalta onneton. Kantilaisen katastrofin myötä ajattelu ja oleminen tulevat toisistaan riippuvaisiksi, eikä meillä Meillassoux'n sanoin "enää ole pääsyä mihinkään muuhun kuin subjektin ja objektin väliseen suhteeseen eikä kumpaankaan toisesta riippumatta" (Après la finitude, jatkossa AF, sivu 18). Tätä on Meillassoux'n mukaan korrelationismi, perinnettä vaivaava erhe.
Toisin kuin yleensä ajatellaan, tämä katastrofi koskee Meillassoux'n mukaan myös Kantin jälkeistä saksalaista idealismia ja Hegeliä. Kant vetää ratkaisullaan perässään koko saksalaisen idealismin. Tässä tapahtuu Meillassoux'n jäsennyksen mukaan jotakin, mitä ei Kantin kohdalla ole usein huomattu. Kopernikaaninen käänne tieteessä ei suinkaan tapahdu vastaavalla tavalla filosofiassa vaan on itse asiassa ikään kuin "ptolemaioslainen vastavallankumous": samalla kun tiede pääsee maakeskisyydestä, ajattelu sulkeutuu subjektikeskeisyyteen, korrelationismin kehään. Siinä missä Kant siis kartesioilaisuuden kritiikissään päätyy muotoilemaan transsendentaalisen idealismin projektin, niin filosofian varsinaiseksi kohteeksi nousevat kokemuksen omat mahdollisuusehdot, ymmärryksen puhtaat käsitteet ja niiden oppina transsendentaalinen logiikka. Näin perinne päätyy tarkastelemaan Meillassoux'n mukaan pelkkää korrelaatiota, subjektin ja objektin, ajattelun ja olemisen suhdetta. Siten kantinlainen katastrofi on, että hukataan vanhan metafysiikan perintö, jossa tehdään vielä ero olion primaaristen (olion matematisoitavissa oleva olemus) ja sekundaaristen ominaisuuksien (meidän aistimisen tapaamme suhteessa olevat ominaisuudet) välillä. Kant tarkastelee vain olion sekundaarisia ominaisuuksia, sillä hänen mukaansa tieto on mahdollinen vain aistimellisen annetun kautta. Oliota sinänsä voi vain ajatella.

Meillassoux'n luenta on provokatiivisimmillaan juuri tässä: kantilainen katastrofi merkitsee Meillassoux'lle pelkästään sitä Kantin tarkoin jäsentämää logiikkaa, jonka kautta tämä pyrkii ajattelemaan äärelli- 
syyttä ymmärryksen ja subjektin tietokyvyn rajoittumisena. Tällöin subjektin syntetisoivan toiminnan kautta syntyvä merkityksellinen maailma asettuu vasten sellaista tekijää, jota tämä tietokyky ei määritelmällisesti voi tavoittaa, mutta joka ei ole siinä mielessä tuonpuoleinen, että se olisi jotakin periaatteessa tavoitettavaa. Kantilainen transsendenssi seuraa siis siitä, että kyse on tietokyvyn omista ehdoista eikä mitään toista tietokykyä, toista esittämisen tapaa ole. Siksi kantilainen äärellisyys ei ole vain yksinkertaista tietokyvyn rajoittumista. Koska tämä raja on tietokyvyn sisäinen, sillä on tietokyvyn ulkopuolisia, niin praktisia eettis-poliittisia kuin esteettisiäkin seurauksia. Meillassoux'n luennassa kyse on ikään kuin vain teoreettisesta järjestä, siitä, ettei tietämisen alueella oteta ratkaisevaa askelta. Tämä tulkinnallinen painotus liittää myös Hegelin tämän katastrofin piiriin. Siinä missä Kantin ajattelu on Meillassoux'n termein vielä "heikkoa korrelationismia", koska olio sinänsä on vielä mahdollinen ajattelun kohteena, niin Meillassoux'n mukaan varsinaista korrelationismia vahvassa mielessä on Hegelin ajattelu. Vahva korrelationismi on kokonaan itseensä sulkeutuva ajattelun kehä, jossa kyllä ajatellaan absoluuttista, mutta pelkästään absolutisoimalla tietävän subjektin ja objektin suhde. Vahvassa korrelationismissa ajateltavana on vain ajattelu itse.

Tämän korrelationismin toivottomimman muodon piiriin Meillassoux laskee niin Heideggerin ja Wittgensteinin kuin erityisesti Derridan. Heille filosofian tieteen raja - tässä Meillassoux ei tee eroa ajattelun ja tietämisen välille samalla tavalla kuin kumoamansa korrelationistit - tarkoittaa aina tiettyä mahdottomuutta, karkeasti sanottuna ajattelun rajoittumista kantilaisella tavalla vasten sen omaa sisäistä rajaa.

Meillassoux ajattelee tässä samoin kuin jälkikantilaiset suhteessa Kantiin: äärellisen ajattelun pitäisi pystyä ylittämään tämä raja ennen kuin ajattelu voi todella edes alkaa. Vahvaa korrelationismia ja äärellisyyden ajattelua määrittää siten teesi, joka tekee tästä ajattelusta Meillassoux'n silmissä kyvyttömän: "On mahdotonta ajatella sitä, että se, mitä ei voi ajatella, on mahdoton (il est impensable que l'impensable soit impossible)" (AF 56). Tässä perinteen heikkouden pisteessä on kuitenkin Meillassoux'n mukaan uuden alku.

\section{FAKTISITEETTI JA OBJEKTIN ETUSIJA}

Spekulaation paluun ja ainakin Meillassoux'n avauksen jäljet johtavat jälleen kerran Pariisiin ja lähinnä jo mainitun Badioun johtamaan ja ENS:ssa toimivaan tutkimusryhmään Centre International d'Etude de la Philosophie Française Contemporaine, johon myös Meillassoux kuuluu. Varsinaisesti keskustelu spekulatiivisesta realismista syntyy Meillassoux'n kirjan julkaisemisen ja myöhemmän englanninnoksen (2008) jälkeen brittiläisissä piireissä.

Vaikka Après la finitude -kirjan väitteet voi tottakai heti liittää yhteen esimerkiksi juuri Badioun projektin kanssa, ainakin periaatteessa Meillassoux'n kirja on manifestimainen essee uudesta metafysiikasta äärellisen lähtökohdan ylivallan jälkeen. Tarkoituksena on näyttää kokonaan uusi tehtäväkenttä vastaavalla tavalla kuin Kant, siis perustamalla uuden metafysiikan periaatteet ja alue, mutta nyt kokonaan toisin.

Meillassoux'n ajatuksena on, että tätä ei ole ennen tehty - ja tällaista julistusta seuraavat reaktiot ovat totutulla tavalla kahdentyyppisiä: joko avaus tuomitaan pelkäksi provokaatioksi ja kumotaan se etsimällä väitteen oletuksista tai sen kehittelystä sopiva virhe koko projektin kumoamiseksi tai sitten manifestin mukaista ohjelmaa lähdetään suorittamaan aivan kuin kyse todella olisi perinteestä irtileikatusta ja kaiken ratkaisevasta uudesta tieteestä. Meillassoux'n herättämässä keskustelussa on turvauduttu molempiin ratkaisuihin.

Sisällöllisesti Meillassoux palaa kysymykseen spekulaation mahdollisuudesta, jota edellä on avattu toisena Hegel-luentana. Tätä esimerkiksi Żižek on hyvin päättäväisesti esittänyt. Mitä tulee Meillassoux'n tulkintaan saksalaisesta idealismista, Žižekin väite on päinvastainen - olematta kuitenkaan vastakkainen. Žižek ei Meillassoux'n tapaan väitä, että perinnettä vaivaisi kantilainen virhe, vaan hän on useaan otteeseen korostanut, että itse asiassa Kantissa on todella kiinnostavaa ja huomionarvoista juuri spekulatiivisuus, Žižekille hegeliläisyys. Perinteisissä tulkinnoissa Kantista ja Hegelistä Kantin on nähty korostavan rajaa siinä, missä Hegel etsii tämän rajan kumoavaa sovitusta. Sen sijaan Žižek ja Meillassoux päätyvät vastakkaiseen johtopäätökseen yhdessä, mutta eri kautta: Meillassoux vasten Kantia ja kantilaista Hegeliä, Žižek taas Hegelin ja hegeliläisen Kantin nimissä.

Keskeistä on tavoite löytää radikaalin spekulatiivisen ajattelun mahdollisuus. Tässä koko liikettä ja vähintäänkin Meillassoux'ta ja Žižekiä yhdistää spekulaatiolle annettu tehtävä: spekulaatio on vastak- 
kaista kaikenlaiselle empiristiselle ja naturalistiselle uskolle totuuden läsnäoloon. Spekulaatio on ajattelua absoluutin läsnäolon hajoamisen jälkeen. Spekulaatiolle totuus on tuolla puolen, mutta ei niin, että tuolla puolen olisi jokin toinen, vaan pelkästään niin, että se puuttuu läsnäolosta. Näin spekulaatio on ajattelua, jonka kohteena on absoluuttinen, ei tuonpuoleisena vaan sikäli kuin esitettävissä oleva absoluutti, koettava välttämätön, puuttuu tämänpuoleisessa. Jos tämä puute tulkitaan tehtäväksi ajatella transsendenssia, päädytään Meillassoux'n termein juuri korrelationismin vahvaan muotoon hankalimmillaan. Jotakin muuta pitäisi olla. Tämän virheen vaikutuspiirissä ei enää kyllä tehdä vanhaa metafysiikkaa, mutta siinä ajatellaan vain filosofisen tietämisen rajaa vailla objektiivista vastinetta.

Meillassoux etsii tapaa murtaa tämä korrelationistinen kehä. Hänen ratkaisunsa perustuu sellaiseen ajattelun perinteen oireelliseen pisteeseen, jossa ajatellaan erityistä kohdetta, joka on sekä ontologisesti perustava että kokonaan vastoin tämän perinteen kohteen objektiivisuudelle asettamia mahdollisuusehtoja. Meillassoux ottaa tässä saksalaisen idealismin peruskäsitteitä omaan käyttöönsä. Hän nimittäin selvittää, kuinka korrelationismi sulkeutuu kehäksi faktisiteetin (facticité) käsitteen kautta.

Kun ajattelu kohtaa kohteen, josta ei voida sanoa muuta kuin että se on, korrelationistinen kehä saa vahvistuksensa: ajattelun törmääminen omaan rajaansa merkitsee korrelationistiselle ajattelulle sen oman totuuden ja ylimmän määrityksen avautumista. Esimerkiksi Kantin ylevä ei siten Meillassoux'n tulkinnassa ole mitään muuta kuin ajattelun pysähtymistä ennen todellisen tehtävänsä hyväksymistä, käsittämisen liikkeen jäämistä alkuunsa. Myös Heideggerilaisessa määrityksessään faktisiteetti toimii Meillassoux'lle tässä samassa tehtävässä. Faktisiteetti on erityisen olevan, Daseinin eksistenssin silkka tosiasia. Se ei ole sitä, että tietty olio olisi sitä taikka tätä, vaan pelkästään että se on. Näin äärellinen ajattelu ei Meillassoux'n mukaan kuitenkaan koskaan tee muuta kuin etsii juuri tällaisten momenttien kautta oman ajattelun piirinsä sulkemista. Tämä tekee ajattelusta niin ontologisessa kuin eettis-poliittisessakin mielessä kyvytöntä. Meillassoux'n yleisempi väite onkin, että metafysiikan loppu on näin välttämättä metafysiikan uskonnollinen loppu ja korrelationistinen ajattelu viime kädessä fideismiä.

Korrelationistisen ajattelun kehän murtaminen on kuitenkin mahdollista tämän perinteen oireellisen täydennyksen kautta. Faktisiteetti on käsite, jolla perinne itse nimeää aavistamansa murtuman. Faktisiteetti on Meillassoux'n mukaan siis aina jo ollut piste, jossa ajattelu avautuu itsensä ulkopuolelle. Nyt on vain kyse ajattelun operaatiosta suhteessa tähän. Meillassoux'n liike on siten kaikessa yksinkertaisuudessaan seuraava: jos korrelationistinen kehä kerran syntyy faktisiteetin suhteellistamisen kautta, niin korrelationismin jälkeinen ajattelu pääsee alkuun, kun faktisiteetti absolutisoidaan. Mitä tämä tarkoittaa?

Meillassoux'n mukaan annettaessa etusija objektille, faktisiteetti ei enää tarkoita ajattelun varmuutta siitä itsestään samassa mielessä kuin korrelationismissa, vaan sitä että nyt faktisiteettina näyttäytyvä voi olla äärettömästi muu- ta kuin mitä se näyttää olevan. Nimenomaan tämä tosiasia on absolutisoitava.

Edellä kuvatusta ajatuskulusta seuraa Meillassoux'n mukaan filosofinen uutuus: perinteen ajatteleman välttämättömyyden periaatteen uudelleen tulkinta. Meillassoux nimittäin johtaa faktisiteetin absoluuttisuudesta perusteettomuuden, syyttömyyden ja järjettömyyden periaatteen, principe d'irraison. Tämä tarkoitaa sitä, että "millään ei ole syytä olla tai pysyä sellaisena kuin on; kaiken täytyy ilman syytä voida olla olematta ja/tai voida olla toisin kuin on" (AF 82). Näin ei suinkaan päädytä jonkinlaiseen relativistiseen tilaan vaan nimenomaan uuteen absoluuttiseen, joka on sitä, että mikään yksittäinen oleva ei voi olla välttämätön. Korrelationistinen kehä murtuu siis faktisiteetin kautta, siitä samasta pisteestä, jonka avulla korrelationismi onnistui sulkemaan kehänsä, mutta joka nyt tarkoittaa ajattelun pääsyä ulos itsestään. Meillassoux väittääkin, että tätä kautta metafysiikka tulee uudelleen mahdolliseksi. Se mikä pysyy, siis se, mikä on ajatonta - ajatonta siinä mielessä, että on katko suhteessa kokemuksen jatkuvuuteen eli siihen että on syy - on oleminen vailla syytä, perusteettomuus, irraison: "Vain perusteettomuus on ajateltavissa ikuiseksi, koska vain perusteettomuus on ajateltavissa anhypoteettiseksi $j a$ absoluuttiseksi. Siten voidaan sanoa, että on mahdollista osoittaa kaikkien asioiden eivälttämättömyyden absoluuttinen välttämättömyys. Toisin sanoen on mahdollista perustella - epäsuoran osoituksen kautta - kaikkien asioiden kontingenssin absoluuttinen välttämättömyys.” (AF 84.) 


\section{KONTINGENSSI JA MATEMAATTINEN}

Periaatteessa Meillassoux'n osoittamassa äärellisen ajattelun jälkeisessä lähtökohdassa on siis kysymys siitä hämmentävästä tilanteesta, johon joudutaan, kun ajattelun löytämästä säännönmukaisuudesta päästetään irti. Mitä tapahtuu siinä, mikä ajattelulle on kaaosta? Meillassoux'n termein kyse on "hyper-kaaoksesta", tasosta, jota ei pidä käsittää säännönmukaisuuden negaatioksi, kuten korrelationismi tekisi, parhaimmillaankin, vaan välinpitämättömyydeksi suhteessa sääntöön.

Meillassoux vaatiikin palaamista brittiempiristien vaalimaan lähtökohtaan, joka tunnetaan Humen ongelmana: meillä ei pitäisi olla mitään syytä ajatella, että tulevaisuutemme on menneisyyden kaltainen. On kysyttävä, miltä pohjalta meillä on oikeus ajatella, että tiettyillä asioilla on aina samat seuraukset? Mikä takaa lain lainmukaisuuden? Tähän spekulaatio Meillassoux'n mielessä vastaa, että ehdottomasti ei mikään. Mikään esitettävissä oleva, siis mikään kokemukselliseen jatkumoon sijoittuva tekijä ei oikeuta tätä.

Tässä spekulaatiossa ei ole kuitenkaan kyse skeptisismistä, vaan se tähtää juuri siihen kysymykseen, mikä saksalaisessa idealismissa on ollut pelissä aina Kantista alkaen. Kun kokemus loppuu, alkaa jokin muu - Kantille se on transsendentaalinen logiikka, Hegelille filosofian tiede, Schellingille myytti. Meillassoux korostaa, että tässä on uuden metafysiikan alku. Kokemuksen kannalta faktisiteetti tarkoittaa kaaosta, mutta Meillassoux'n mukaan tämä kaaos on järjestyvä, ja nimenomaan tämä kokemuksen tuollapuolen järjestyvä on metafysiikan ja ontologian kohde. Kaaoksella on kuin onkin eksakti kuvaus.

Kun jokaisen äärellisen olion mahdollisuusehto on ääretön siinä mielessä, että se ei voi tulla itse äärellisesti esitetyksi, niin voisi päätellä, että tämä ääretön jää vaille kuvausta. Matematiikka modernin analyysin merkityksessä osoittaa kuitenkin asian olevan toisin.

Meillassoux käyttää hyväkseen sitä, että juuri siinä, missä moderni analyysi on nimenomaan tiede äärellisen ja kvantitatiivisen ylittävästä, se näyttää lainmukaisuuden kokemuksellisuuden tuolla puolen. Modernin analyysin klassikkona Georg Cantor onkin Meillassoux'n manifestin keskiössä. Vastaavalla tavalla kuin Cantor näytti, kuinka äärettömän analyysi on mahdollinen, Meillassoux osoittaa, että ontologian on mahdollista olla eksakti tiede. Cantorin keskeinen huomio oli, että siinä, missä matematiikka välttämättä päätyy äärettömän käsitteeseen, se ei silti saa jättää sitä symboliseksi rajaksi, äärellisen ja kvantitatiivisen aritmetiikan tuonpuoleiseksi. On nimittäin mahdollista muodostaa äärettömän analyysi, äärettömyyksiä koskeva kuvaus ja järjestys. Tässä mielessä Cantorin kautta tulee perustelluksi väite siitä, että joukkojen joukkoa ei ole, siis että joukko, joka sisältää kaikki osajoukkonsa, ei voi sisältyä siihen itseensä. Ä̈rettömät joukot, joihin näin välttämättä päädytään, eivät kuitenkaan ole kuvauksen tuolla puolen. Cantorin teesi nimittäin on se, että äärettömällekin joukolle voidaan aina määrätä tietty kvantiteetti, mitta, sen mahtavuus. Tämän takia ääretön ei joukko-opille ole laskettava äärellinen eikä laskettamattomissa oleva yksinkertainen ääretön, vaan tietty mitattava ääretön, siis ei finiitti eikä infiniitti, vaan transfiniitti.

Suhteestaan ajatteluun vapautettu faktisiteetti näyttää järjestyksen, joka näin on kokemuksen ja äärellisen ajattelun kannalta kyllä kaaos, mutta Meillassoux'n mukaan kuitenkin luonteeltaan matemaattinen. Kaaoksen järjestys, siis eräässä mielessä joukkojen joukko, on kyllä ääretön, mutta nyt transfiniitti, modernin analyysin joukko-opin piirissä ja siksi lainmukainen.

Meillassoux'n operaatio pitää sisällään kaksi liikettä. Yhtäältä koko väite on suunnattu sitä illuusiota vastaan, että ääretön jäisi järjestyksen tuolle puolen. Tarkoitus on juuri näyttää, että metafysiikan on oltava mahdollinen muutenkin kuin pelkkänä korrelaation tarkastelemisena. Toisaalta väite on, että tämä metafyysinen ei koskaan voi olla läsnäoleva. Filosofian on nähtävä läsnäolevan määrityksen tuolle puolen ja kyettävä huomaamaan, että mikään yksittäinen esitys ei ole totuuden jäännöksetön esitys. Hegelin sanoin tieteen on päästävä "luonnon kovan kuoren läpi" (Estetiikan luennot). Kokemuksen kannalta tämä kuitenkin tarkoittaa vain sitä, että totaliteetti puuttuu. Meillassoux esittääkin, että Cantorin teesin voi kääntää tähän yhteyteen seuraavasti: "ajateltavissa olevan (kvantifioitava) totaliteetti on mahdoton ajatella." (AF 144.)

Filosofian on siis päästävä siihen pisteeseen, jossa se yhtäältä voi käsittää perustavan järjestyksen laskemattomuuden ja toisaalta voi ottaa tämän laskemattoman tehtäväkseen. Kaikissa eettis-poliittisissa seurauksissaan tehtävänä on nähdä laskettavissa olevan raja, mutta niin, että vasta tältä rajalta, josta laskemattomissa oleva avautuu, filosofian teh- 
tävä alkaa.

Vaikka Meillassoux peräänkuuluttaakin spekulaation uutta paluuta, edellä kuvatussa hänen yrityksensä erottautua saksalaisesta idealismista tulee esiin: laskemattomissa olevan järjestyksen tehtävä on kohdattava Meillassoux'n mukaan objektissa, ei filosofian itsensä sisällä, esimerkiksi sen omien mahdollisuusehtojen tarkasteluna, transsendentaalisten rakenteiden kuvauksena tai edes filosofisten tieteiden systeeminä. Tämä nimittäin olisi spekulatiivista ajattelua idealismina. Vaikka tässä kohtaa eronteko on viime kädessä mahdotonta, Meillassoux'n väite on, että juuri idealismi tekee saksalaisesta spekulaatiosta korrelationismia. Siinä absoluuttista määrittää aina jo ennalta asetettu suhde ajatteluun. Kuten jo todettiin, Meillassoux'n erottautuminen tapahtuu sitä kautta, että absoluuttiseksi asetetaan faktisiteetti, olioiden oma kontigenssi, olioiden voima olla äärettömästi muuta kuin mitä äärellinen tietoisuus ja ymmärrys sanoo. Descartes'n perintö näyttäytyy vaatimuksessa, että ajattelun on avauduttava loputtomasti sille, että oliot ovat ajattelusta riippumatta ja siksi äärettömästi toisin. Tätä toisin olemista ei kuitenkaan voi jättää yhdentekeväksi kuten tekee nykyranskalainen "toiseuden ajattelu", joka Meillassoux'n mukaan on tässä pahinta laatua.

Meillassoux toistaa sen, mitä Badiou on pitkään esittänyt: ontologia on käsitettävä matematiikaksi, ei aritmetiikkana vaan modernina analyysina joukkoopin mielessä. Matemaattisen tieteen voima on siinä, että se osoittaa, kuinka asiat ovat muuta kuin miltä ne näyttävät. Siksi Meillassoux'n manifestin asettama viimekätinen tehtävä on ajatella "matematiikan spekulatiivista tärkeyttä" ja "absolutisoida tämä matematiikan tärkeys" (AF 174).

\section{LOPUKSI: SAKSA - RANSKA}

Saksalaisessa Kantin jälkeisessä idealismissa spekulatiivisuuden ydin oli siinä, että yksittäisen tietoisuuden, tietokykyjen ja kokemuksen sijaan filosofian omin alue on jotakin muuta. Hegelin absoluuttinen henki, ja jos näin voi sanoa, totuuden diskurssi, seuraa käsitteelisesti vasta objektiivisuuden jälkeen. Tämä totuuden piiri avautuu vasta sitten, kun objektiivista henkeä määrittävä olioiden läsnäolo murtuu. Hegelille tämän murtuman saa aikaan taide ja käsitteen kannalta kehittyneemmin uskonto ja filosofia. Taide herättää hengen objektiivisuudestaan.

Meillassoux osoittaa sen sijaan, että tämän herätyksen pitäisi tulla tieteen suunnasta. Samalla tavalla kuin Kantin herätti wolffilaisen dogmaattisuuden unestaan Humen empirismi, luonnontieteiden tarjoamien kovien faktojen pitäisi herättää meidät. Niihin nimittäin sisältyy momentti, jonka pitäisi pistää filosofia liikkeelle. Meillassoux esittää, että koviin tieteisiin sisältyy tiettyjä väitteitä, jotka ovat määritelmällisesti vastoin kokemusta. Tällaiset ylimuistoiset tosiasiat, joita Meillassoux kutsuu ansestraalisiksi (ancestralité), näyttäytyvät ja tarjotaan meille tosiasioina, siis kokemuksellisestikin kaikkiin muihin tosiasioihin rinnastettavina siitä huolimatta, että niiden määritykseen kuuluu niiden kokemisen absoluuttinen mahdottomuus. Kyse on sellaisista faktoina esitetyistä asioista kuin maapallon synty ja ihmistä edeltävä orgaaninen elämä.

Nämä absurdit faktat esittävät ajattelulle Meillassoux'n kaipaaman haasteen. Kyse ei ole siitä, että ne pitäisi ottaa tieteen antamassa muodossa, muttei myöskään siitä, että ne pitäisi kokemuksen puuttuessa kumota. Päinvastoin juuri ne tarjoavat mahdollisuuden ajatella maailmaa ilman ajatusta, spekuloida. Näin käy ilmi, että tiede velvoittaa meidät ajattelemaan absoluuttista. Tällä tieteen piirin absoluuttisella on kuitenkin yhä sama rakenne kuin absoluutilla kokemuksen kannalta. Absoluuttista on välttämättömän ja absoluuttisen olevan puute. Kuitenkin, toisin kuin tervejärkisessä kokemuksessa, jossa tämä puute onnistuu kätkeytymään, modernissa luonnontieteessä on alkanut esiintyä tällaisia absoluuttisia pisteitä. Tieteessä kokemuksen raja tulee esiin, ja juuri tämä on osoitus matematiikan voimasta. Kun kvanttifysiikan mukaan on vain tietty todennäköisyys (joskin turvallisen suuri) sille, että kiviseinää päin kävellessä todella törmäämme siihen, sen sijaan, että pääsisimme sen läpi, niin tämä on paljon todempaa kuin se luottamus kovaan faktaan, jonka aistimme antavat ja josta äärellinen ajattelu onnettomasti pitää kiinni. Vaikka edellinen ei tietenkään kelpaa filosofiseksi väitteeksi, niin Meillassoux'n mukaan sen pitäisi ainakin herättää filosofia.

Meillassoux ja erityisesti hänen innoittamansa keskustelu korostavat, että näin avautuva tiede on käsitettävä uudeksi materialistiseksi ajatteluksi, spekulatiiviseksi realismiksi ja materialismiksi. Materialismia on tässä se, että ideaalinen eli kokemusta säätelevä ykseys ja sen tuoma varmuus puuttuvat.

Tässä kohtaa ero saksalaisen idealismin spekulatiivisuuteen tulee kuitenkin hankalaksi tehdä. Meillassoux'lle ero on 
selvä, mutta toisenlaisiakin väitteitä on esitetty. Slavoj Žižek nimittäin väittää, että juuri tässä kohtaa ajattelun on oltava hegeliläistä. Žižekin mukaan Hegelin uudelleen lukeminen on tehtävä siksi, että juuri nyt, kun tiede näyttää meille kaikkien identiteettien ja ykseyksien romahtamisen, subjektiviteetin kysymys palaa juuri siinä muodossa kuin se on luettavissa Hegeliltä. Vastaavalla tavalla myös ranskalainen Catherine Malabou on näyttänyt, kuinka Hegelin tekstistä luettavissa oleva käsitteen liike, sen plastisiteetti, on ajattelun mahdollisuus nähdä se, mikä tulee, ilman että otetaan takaaskel vanhan metafysiikan identeettiajatteluun.

Žižekille Hegel-luennan kautta on mahdollista avata sellaista olemuksen ja identiteetin ajattelua, jossa olemusta ajatellaan aina tuotettuna, mutta ilman että kyse olisi subjektin sisäisestä liikkeestä. Sen, mikä jää äärellisen tuolle puolen, voidaan esittää vain tuonpuoleisen puutteen kautta. Absoluuttinen on vain se, että suhteellisesta puuttuu kokonaisuus. Toisin sanoen absoluuttista on se, mikä näyttää, ettäabsoluuttinen on näennäinen, se missä ilmiasu ilmenee ilmiasuna.

Žižekin muotoileman ajattelun projektin voisi sanoa olevan saksalaisen idealismin projekti alunperinkin. Žižek muotoilee asian Markus Gabrielin kanssa kirjoittamassaan tekstissä seuraavasti: "Saksalaisen idealismin tarkoituksena oli toteuttaa siirtymä epistemologiasta uuteen ontologiaan ilman taka-askelta esi-kriittiseen metafysiikkaan. Se sijoitti oletetun absoluutin [...] ja suhteellisuuden [...] välisen katkoksen absoluutin itsensä sisään. Nykyisen jälkikantilaisen ajattelun tehtävä on selvittää tämän siir- tymän merkitys" (Mythology, Madness and Laughter, 5).

Ajatuksena on siis se, että saksalaisen idealismin jättämänä perintönä on filosofian tehtävä absoluutin ajattelemisena. Lainauksen termein kyse on siitä, että epistemologiana filosofia on aina äärellistä. Absoluutti ei kuitenkaan tarkoita sitä, että osittaisen ja suhteellisen ilmenevän, ja tässä mielessä näennäisen, sijaan esitettäisiin kokonainen. Tämä olisi yhä liian kantilaista, Meillassoux'n esseen termein korrelationismia. Absoluuttinen on vain näennäistä, siis ilmenevää, vaivaava puute, se että näennäinen näyttäytyy näennäisenä. Tätä tarkoittaa "absoluuttisen sisäinen katkos", itse absoluutti katkoksena. Juuri tässä muodossa Hegelin voi sanoa palaavan uutena materialismina ja spekulatiivisuutena. Siinä missä moderni luonnontiede päätyy kovien faktojen ja luonnostaan pysyvien materiaalien sijaan löytämään pelkkiä energioita, tai siinä missä tietoinen mieli vaikuttaa palautuvan hermokudokseksi, ilmaantuu viimekätinen kysymys, ei perimmäisestä olevasta, vaan identiteetistä, itseydestä ja subjektiviteetista tässä avautuvassa moneuden kuilussa.

Hegeliläisen Hegelin käsitetään väittävän, että olion olemus on aina jo olevan olion kehityksen teleologisessa horisontissa. Tässä mielessä olemisen tapahtuma, aito sattuma siinä mielessä, että se ei olisi minkään, edes transsendentaalisen välttämättömyyden piirissä, olisi mahdoton. Olion näennäisyyskin olisi sitä, mitä sen pitää olla, jotta käsittämisen kokonaisuuden liike etenee kohti sitä, mitä se aina jo on. Hegelin logiikan keskeinen väite on kuitenkin se, että olemus pelkkänä jälkikätisyytenä on loogista, ei kronologista.
Välttämättömyys on looginen määritys. Kokemuksen kannalta sen toinen on pelkkä looginen tila, jälkikätisyys, jonne sen ei ole lupa päästä. Kokemuksen toisella puolella on filosofian tiede, ajattelun työ, joka kokemuksen kannalta on aina pelkkä puhdas alku. Siinä, että olio todella ilmaantuu kontingenttina, jonakin muuna kuin se on, on tarjolla Žižekin sanoin, reflektiivinen oikosulku, jossa olio kieltäytyy olemasta tiedon kohde. Se ei antaudu tiedettäväksi vaan antaa ajateltavaa. Tämän voi väittää olevan materialismia spekulatiivisessa mielessä, tai kuten Žižek muotoilee: "Materialismia ei ole suora väite siitä, että kuulun objektiiviseen todellisuuteen [...]. Pikemminkin materialismi on löydettävissä siitä reflektiivisestä väännöstä, jonka kautta minä itse sisällyn konstituoimaani kuvaan. Omasta 'materiaalisesta olemassaolostani' todistaa tämä reflektiivinen oikosulku, tämä itseni välttämätön kahdentuminen, itsen joka on sekä kuvani sisäpuolella että ulkopuolella. Materialismi tarkoittaa sitä, että todellisuus, jonka näen, ei koskaan ole 'kokonainen' ei siksi, että suuri osa siitä jää tavoittamattomiini, vaan koska siihen kuulu sokea piste, joka merkitsee minun kuulumiseni siihen." (The Parallax View, 17.)

Näin Meillassoux'n projektin voisi nähdä toisinkin. Žižekin kanssa kirjoittanut saksalainen Markus Gabriel onkin tässä Žižekin puolella ja päätyy itse asiassa väittämään, että Meillassoux'n ajattelu on eräänlaista tiedeuskoa.

Tämän väitteen kohdallisuutta voi arvioida lähtien siitä, miten pitäisi ymmärtää Meillassoux'n ja Badioun matemaattinen ontologinen taso. Siinä että kontingenssin ja ta- 
pahtuman kuvaus erotetaan äärellisen näkökulman lainmukaisuudesta, ollaan vielä samalla maaperällä saksalaisen idealismin kanssa, mutta kun tämä kuvausten kuvaus, lain lainmukaisuus samaistetaan matematiikan kanssa, on välttämättä kysyttävä sitä, mikä takaa matematiikalle, oli se sitten määritelty miten tahansa, sen erityisen aseman merkityksellisyyden äärettömyytenä. Gabrielin väite onkin se, että itse asiassa joukko-oppi ontologiana edellyttäisi joukko-opin oman merkityksellisyyden paradoksaalista äärellisyyttä. Gabrielin mukaan asia pitäisi muotoilla radikaalimmin niin, että joukkojen joukon sijaan täytyy ajatella sellaista absoluuttista, joka ei tule suoraan minkään diskurssin piiriin. Joukko-oppi ei siis itse voi esittää olevansa kuvaus vailla sen kuvauksen mahdollistavia ehtoja, joukkojen joukkoa. Joukko-oppi ei käy kuvaukseksi äärettömästä, sillä se itse ei ole ääretön merkityksellinen, ja siksi se ei voi mestaroida tätä ääretöntä. Tämän sijaan Gabriel väittää, että kysymys johtaa välttämättä tieteen, myös matematiikan ulkopuolelle. Kontingenssin suhteen mikään yksittäinen taho ei voi päättää. Asioiden etusijan myöntäminen johtaa siis kyllä yhteisöön, kuten Meillassoux esittää, mutta toisin kuin Meillassoux'lle, jolle tämä yhteisö on tiede, Gabriel korostaa, että näin syntyvä yhteisö on reflektion yhteisö, joka "vastustaa sitä että transsendenssi voisi koskaan saada määrättyä muotoa" (Mythology, Madness and Laughter, 89). Meillassoux'n yhteydessä voikin Gabrielin mielestä harkita uudelleen sitä ranskalaisten ja saksalaisten samanhenkisyyttä, jonka Georges Bataille panee merkille erona suhteessa britteihin. Tunnetussa "öisessä keskustelussaan" vuonna 1951 Maurice Merleau-Pontyn, Georges Ambrosinon ja loogisen positivistin A.J. Ayerin kanssa Bataille hämmentyy siitä kuilusta, joka vaikuttaa erottavan ranskalaiset filosofit "englantilaisista filosofeista", kun puheeksi tulee se, voiko auringon ihmistä edeltävää olemassaoloa epäillä. Ayerille aurinko on aurinko, käsittipä sen yksilö ja tiede tai ei. Tällaista asennetta Bataille ei voi käsittää ja huomauttaa, että saksalaiset sentään vaikuttavat olevan ranskalaisten kanssa samalla puolella kuilua. 